\title{
REVIEW
}

\section{Realignment of sea turtle isotope studies needed to match conservation priorities}

\author{
Ryan M. Pearson ${ }^{1, *}$, Jason P. van de Merwe ${ }^{1}$, Colin J. Limpus ${ }^{2}$, Rod M. Connolly ${ }^{1}$ \\ ${ }^{1}$ Australian Rivers Institute - Coast \& Estuaries, and School of Environment, Griffith University, Gold Coast Campus, \\ Parklands Drive, Queensland 4222, Australia \\ ${ }^{2}$ Threatened Species Unit, Department of Environment and Heritage Protection, Brisbane, Queensland 4102, Australia
}

\begin{abstract}
Stable isotope analyses have become popular in sea turtle literature over the past decade, with an increasing year-to-year trend in published studies reporting insights into food web structure, diet, trophic interactions, ontogenetic shifts, geographic distributions, and more. Understanding the geographic distribution of migrating taxa within their sub-populations could enhance conservation and management, especially for threatened populations. For sea turtles, stable isotope analyses can potentially be used to quickly assess foraging distributions across large proportions of a nesting population, examining high numbers of turtles at low cost and/or effort relative to satellite telemetry and mark-recapture studies. We systematically assessed the literature, aiming to identify the current state of research into sea turtle isotope ecology, including key knowledge gaps and the level of geographic assessment within regional management units (RMUs). Sea turtle RMUs listed as Least Concern by the IUCN ( 6.5 studies per RMU) have been studied at a rate 13 times higher than those considered Threatened ( 0.5 studies per RMU). Loggerhead turtles Caretta caretta and green turtles Chelonia mydas are the most studied species. Comparatively, flatback Natator depressus and Kemp's ridley Lepidochelys kempii turtles return a paucity of analyses. This is the first review of sea turtle isotope studies and helps to refocus future isotope research to prioritise conservation outcomes throughout the world. The mismatch between effort and conservation priority may be a testimony to the effectiveness of research and management in these areas but suggests a need to now realign the focus of sea turtle isotope ecological studies towards more threatened RMUs.
\end{abstract}

KEY WORDS: Conservation $\cdot$ Marine turtle $\cdot$ Megafauna $\cdot$ Sea turtle $\cdot$ Stable isotope $\cdot$ Tracking ${ }^{13} \mathrm{C} \cdot{ }^{15} \mathrm{~N}$

\section{INTRODUCTION}

Managers of large, widespread marine taxa often benefit from understanding their movement and resource use. Various techniques have been employed for understanding these parameters at all scales, from individuals to populations, with new techniques regularly being developed. Marine turtles are one type of long-lived, late-maturing species that often undergo extensive trans-oceanic migrations. This makes them vulnerable to a wide range of threats that are difficult to assess and manage, particularly across international borders. Genetic studies have identified sub-populations (genetic stocks) of all 7 sea turtle species, classifying them into discrete management units (MUs; FitzSimmons \& Limpus 2014), or aggregating them into regional management units (RMUs; Wallace et al. 2010). Geographically separated RMUs may be exposed to different threats and stressors; hence, different management strategies may need to be employed within each (Seminoff \& Shanker 2008). 
Recently, the International Union for Conservation of Nature (IUCN) assessed 16 (of 58 total) RMUs (IUCN 2016) to assign them each an individual threat status separate from the global species-level status. This is likely in response to views that traditional global statuses are not useful for sea turtles (e.g. Seminoff \& Shanker 2008). Recent sub-population assessments of loggerhead Caretta caretta (Casale \& Tucker 2015), leatherback Dermochelys coriacea (Wallace et al. 2013) and green turtle Chelonia mydas (Pilcher et al. 2012) RMUs represent a significant step toward more effectively assigning conservation priority. Within each RMU it is also desirable to understand regional distributions and resource use across sub-populations. Stable isotope analysis (SIA), which compares the ratios of light to heavy isotopes of naturally occurring elements in living organisms (DeNiro \& Epstein 1978, 1981), may be able to fill knowledge gaps in these areas.

SIA has been used extensively in marine and terrestrial ecology for understanding diet resources, food web structure, trophic positions, anthropogenic influences, habitat use, and geographic movement (see Rubenstein \& Hobson 2004 for review). For marine turtles, the field of isotope ecology has boomed in recent years and provides valuable insight into their feeding and spatial ecology (Jones \& Seminoff 2013).

Isotopic ratios in marine animal tissues change predictably with environmental gradients, driven by water chemistry and/or resource use. Changes in abiotic conditions (e.g. temperature or salinity) along latitudinal or estuarine-to-offshore gradients can affect isotope ratios in animal tissues by altering isotopic ratios in the water itself (for $\mathrm{O}$ and $\mathrm{H}$ isotopes) and the organisms (primarily $\mathrm{C}, \mathrm{N}$, and $\mathrm{S}$ ) that exist within it (e.g. phytoplankton) (Fry 2006, Tagliabue $\&$ Bopp 2008). These baseline differences are then reflected throughout the food web in the metabolically active tissues (e.g. skin/blood) of higher trophic animals, often with some predictable trophic enrichment.

$\mathrm{C}$ and $\mathrm{N}$ isotopes are the most commonly utilised in ecological studies, including for sea turtles (Jones \& Seminoff 2013, this study). C isotopes are known to exhibit minimal trophic discrimination, while $\mathrm{N}$ ratios increase predictably with trophic level (e.g. McCutchan et al. 2003). Thus, these elements are commonly used for understanding the trophic position in which an animal feeds (using N), and the primary producers at the base of the food web (using $\mathrm{C}$ ). $\mathrm{C}$ isotopes are particularly useful for delineating resource requirements and as a proxy for habitat use, because of distinct differences in baseline $\mathrm{C}$ ratios in different habitats (e.g. Hatase et al. 2010, Howell et al. 2016). $\mathrm{N}$ isotopes have also been used to distinguish between habitats due to fundamental differences in the baseline values of primary producers (e.g. Hatase et al. 2010, Seminoff et al. 2012). However, because of the trophic influence on $\mathrm{N}$ isotopes, it can be difficult to separate the effect of baseline differences and trophic enrichment using bulk tissue analyses alone. Compound-specific isotope analysis techniques (CSIA) have be used to make this distinction by comparing isotope ratios in specific amino acids which react differently with trophic influence (e.g. Seminoff et al. 2012). Further, isotopes ( $\mathrm{O}$ and $\mathrm{C}$ ) in metabolically inactive carbonate materials (e.g. barnacle shells) are known to reflect the water conditions under which they were formed rather than diet, allowing differentiation of geographic locations based on water temperature or salinity (Killingley \& Newman 1982, Killingley \& Lutcavage 1983).

Thus, with multiple ways to distinguish between diets, habitat types, and areas, SIA has become particularly useful for understanding the spatiotemporal distributions of marine turtles within RMUs. Until recently, understanding the geographic distribution of individuals in space and time relied heavily on extensive mark-recapture and/or satellite telemetry studies (e.g. Balazs 1980, Godley et al. 2003), both of which may yield low replication through limited tag application and recovery in some areas, or the high costs (and hence small sample size) associated with telemetry. However, an increase in these types of studies, with concurrent SIA components has allowed the development of sea turtle isoscapes (maps of known isotopic ratios in space and time) (e.g. Ceriani et al. 2014, Vander Zanden et al. 2015), which can be used to assign home areas to migrating individuals. Genetic studies also offer valuable insight into population structure, with some geographic resolution (e.g. Bowen 1995, FitzSimmons \& Limpus 2014) but cannot often distinguish between foraging habitats within an RMU.

This paper presents a systematic and quantitative assessment of the literature on sea turtle isotope ecology, with the aim of informing management decisions and guiding the focus of future sea turtle isotope studies. Specifically, we aimed to answer the following questions: (1) How have isotopes been used to understand sea turtle ecology? (2) What is the state of isotope-derived knowledge for each species within their RMUs? (3) What are the priorities for future isotope research on marine turtles? 


\section{METHODS}

\section{Literature search}

We conducted a search for papers written in English, of type 'article' on Web of Science, Scopus, and Google Scholar on 15 August 2017 . The following string of search terms was used on Web of Science: TOPIC ('sea turtle*' OR 'marine turtle*' OR 'loggerhead turtle*' OR 'green turtle*' OR 'leatherback' OR 'hawksbill' OR 'flatback' OR 'Kemps ridley' OR 'Kemp's ridley' OR 'olive ridley') AND ('isotope*'). The terms used in both Google Scholar and Scopus were identi$\mathrm{Cal}_{i}$ however, slightly different functionality between the platforms necessitated different search strategies. In Scopus the search was in 'TITLE-ABSTRACTKEYWORDS' for turtle terms but only 'KEYWORDS' for the 'isotope *' term. This method was selected because the majority of papers returned when searching for 'isotope*' in TITLE-ABSTRACT-KEYWORDS did not fit the selection criteria. In Google Scholar, the first 200 articles (ranked on relevance) were assessed. At this point no new papers had been identified for 70 articles.

We chose to use common names instead of scientific names for 3 reasons. First, the common names for sea turtles are well accepted and prolific in the literature. Second, character limits within search boxes (especially on Google Scholar) prevented inclusion of all varieties of both types of name. Lastly, concurrent searches on Web of Science including common names only, and then both common and scientific names yielded identical results, indicating that the above set of terms captured all relevant studies.

To be included in the analyses, a paper must have been primary research from a peer-reviewed publication that included isotopes to understand an aspect of marine turtle ecology. Reviews, theses, and grey literature (e.g. conference abstracts) were not included. We then assessed the species and locations studied within these papers and assigned each into the RMUs described by Wallace et al. (2010).

\section{RMU threat status}

Only 18 of the 58 RMUs identified by Wallace et al. (2010) have had individual assessments conducted by the IUCN, all since 2012 (IUCN 2016). Loggerhead turtles have had all 10 and leatherback turtles all 7 of their RMUs assessed. Green turtles have had only 1 (of 17). The remaining 40 RMUs have not been assessed under IUCN Red List criteria. We used the threat status of an RMU in subsequent analyses only if it has been subject to an individual IUCN assessment, with one exception: Kemp's ridley turtles only have one recognised $\mathrm{RMU}_{\text {; }}$ thus, we consider the species-level 1996 IUCN assessment to qualify also as a sub-population assessment for our purposes. This left 19 assessed and 39 unassigned RMUs in our analyses. We acknowledge that assessments beyond the IUCN have been conducted on some (or all) of these unassigned RMUs (e.g. Wallace et al. 2011 and the USA's national recovery plans); however, we consider these assessments to be incomparable for the purposes of our analyses due to threat levels that conflict with the more recent IUCN Red List assessments and/or differences in definitions of MUs and/or threat categories.

\section{RESULTS AND DISCUSSION}

\section{Marine turtle isotope ecology - an overview}

We identified 96 studies that satisfied the selection criteria (see Table S1 in the Supplement at www.intres.com/articles/suppl/m583p259_supp.pdf for full list of papers). Loggerhead turtles (56 studies) have been the subject of the majority of isotope studies globally, followed by green turtles (36). The remaining species have been investigated in comparatively few studies, with flatback turtles being completely absent from the isotopic literature.

\section{Isotopic techniques used in marine turtle ecology}

In total, 7 key study types were identified that we classified into 2 broad categories: methodological and geographic (Fig. 1). We classified methodological studies as those that aimed to develop an understanding of the mechanisms behind isotopic changes in turtle tissues. These were assigned to 5 key categories: diet-tissue relationship; tissue-tissue relationship; isotopic and/or metabolic turnover; sample preservation and/or preparation; and fossil isotopes (Fig. 1). Five studies were identified as methodological but did not align with one of our 5 sub-categories or have sufficient similarities to justify forming an additional category (Table S1).

Diet-tissue studies incorporated those investigating wider ecological concepts in food-web structure/resource use and ontogenetic shifts outlined in Table 1. Tissue-tissue studies also addressed ontogenetic concepts in some cases. We considered fossil 


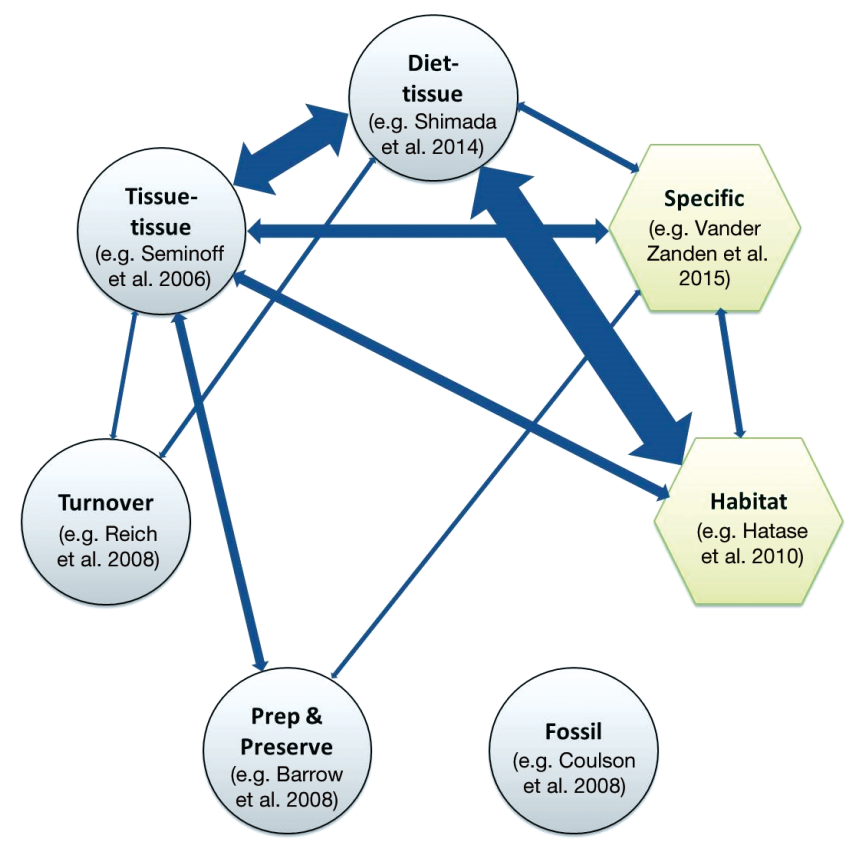

isotopes to be of minimal relevance to current conservation priorities and therefore did not explore this category any further here (see Coulson et al. 2008 for this type of study). Geographic studies were classified as those that aimed to assign turtles to either a specific geographic foraging area (specific location), or distinguish between habitat types, predominantly oceanic versus neritic feeding (habitat discrimina-
Fig. 1. Types of studies identified and the relationships between each type. Green hexagons = geographic studies. Habitat: studies that distinguish between use of habitat types; specific: studies that place turtles in specific geographic locations/foraging areas. Grey circles = methodological studies. Diet-tissue: investigations of the relationship between isotope ratios in prey items and turtle tissues; tissue-tissue: investigations of differences in isotope ratios between various turtle tissues; turnover: investigations of the rate of isotopic turnover in turtle tissues; prep \& preserve: investigations of the effect of methodological techniques (preservatives and/or sample preparation methods) on isotope ratios; fossil: analysis of isotope ratios from sea turtle or epibiont remains $>500$ yr old. Arrows between categories represent the number of studies that were placed into both categories, where thicker arrows mean more pairings

tion) (Fig. 1). Two studies, although they did analyse isotopes from sea turtles, were excluded from analyses because they were judged to be investigating the ecology of beach ecosystems rather than sea turtle ecology directly (e.g. Vander Zanden et al. 2012a).

Defined categories were not mutually exclusive, with many studies exploring questions that covered 2 or more categories. The most common pairings were between studies that investigated both diet-tissue relationships and inferred foraging habitats (habitat discrimination) (16 studies). This was followed closely by those that investigated the relationships between diets (diet-tissue relationship) and multiple tissues (tissue-tissue relationship) (15 studies) (Fig. 1).

Table 1. Isotopic residence times for $\mathrm{C}$ and $\mathrm{N}$ in soft tissues, and the ecological applications each tissue type has been used for. Examples are studies clearly showing applications or testing residence times, not a comprehensive list of all studies within a category. Relevant references can be found in Table S2 in the Supplement at www.int-res.com/articles/suppl/m583p259_supp.pdf. Numbers in superscript match literature examples. Y: at least 1 study has used a tissue for that ecological application. Grey cells represent study types which have not been investigated using a particular tissue type. N/A: not applicable

\begin{tabular}{|c|c|c|c|c|c|c|c|c|c|}
\hline \multirow{2}{*}{$\begin{array}{l}\text { Tissue } \\
\text { type }\end{array}$} & \multirow{2}{*}{$\begin{array}{c}\text { Sub-tissue } \\
\text { type }\end{array}$} & \multicolumn{3}{|c|}{ Approximated residence time } & \multicolumn{4}{|c|}{ Study type: ecological applications } & \multirow{2}{*}{$\begin{array}{l}\text { Literature } \\
\text { examples }\end{array}$} \\
\hline & & Hatchling & Juvenile & Adult & $\begin{array}{l}\text { Geo- } \\
\text { graphic }\end{array}$ & $\begin{array}{l}\text { Food web } \\
\text { analysis }\end{array}$ & $\begin{array}{c}\text { Diet/resource } \\
\text { use }\end{array}$ & $\begin{array}{l}\text { Onto- } \\
\text { geny }\end{array}$ & \\
\hline Skin & & $60-90 \mathrm{~d}^{1}$ & $37-55 d^{1}$ & No sea turtle & $\mathrm{Y}$ & $\mathrm{Y}$ & $\mathrm{Y}$ & $\mathrm{Y}$ & $1,4,5,6$ \\
\hline \multirow[t]{3}{*}{ Blood } & $\mathrm{RBC}$ & $60-85 \mathrm{~d}^{1}$ & $33-43 d^{1}$ & data. Likely & $\mathrm{Y}$ & $\mathrm{Y}$ & $\mathrm{Y}$ & $\mathrm{Y}$ & $1,4,5,15$ \\
\hline & Plasma & $13-26 d^{1}$ & $17-50 \mathrm{~d}^{1, \mathrm{a}}$ & longer than & & $\mathrm{Y}$ & $\mathrm{Y}$ & $\mathrm{Y}$ & $1,4,9,16$ \\
\hline & Whole blood & $33-45 d^{1}$ & $24-55 d^{1, a}$ & juvenile stage ${ }^{b}$ & & & $\mathrm{Y}$ & $\mathrm{Y}$ & 1,4 \\
\hline Scute & & $\begin{array}{l}1 \text { layer: } \\
40-70 \mathrm{~d}^{1}\end{array}$ & $\begin{array}{l}1 \text { layer: } \\
\text { 15-63 d } \mathrm{d}^{1, \mathrm{a}}\end{array}$ & $\begin{array}{l}1 \text { layer: } \\
\sim 0.6 \mathrm{yr}^{17} \\
\text { All layers: } \\
\leq 18 \mathrm{yr}^{2}\end{array}$ & $\mathrm{Y}$ & $\mathrm{Y}$ & $\mathrm{Y}$ & $\mathrm{Y}$ & $1,2,3,7,10,17$ \\
\hline \multirow{3}{*}{$\begin{array}{l}\text { Egg } \\
\text { Muscle } \\
\text { Liver }\end{array}$} & & \multirow{3}{*}{\multicolumn{3}{|c|}{$\begin{array}{l}\text { N/A. Consistent through development }{ }^{14} \\
\text { No sea turtle data. Likely med-long }{ }^{\mathrm{C}} \\
\text { No sea turtle data. Likely short }{ }^{\mathrm{C}}\end{array}$}} & $\mathrm{Y}$ & $\mathrm{Y}$ & $\mathrm{Y}$ & & $11,12,14$ \\
\hline & & & & & & $\mathrm{Y}$ & $\mathrm{Y}$ & & $3,4,8,13$ \\
\hline & & & & & & & $\mathrm{Y}$ & & 4 \\
\hline
\end{tabular}


Within the 7 categories, isotopes of 5 elements have been analysed from 14 tissues (Fig. 2). C and $\mathrm{N}$ isotopes were the most common (C: 84; N: 85; both: 81). We focused an in-depth view of residence times and ecological applications only on studies using these 2 isotopes (Table 1). O was analysed in 7 studies; $\mathrm{S}$ and $\mathrm{Pb}$ in 2 each (Fig. 2). Deuterium was also used in 3 studies, but always as a component of doubly labelled water, which was injected into turtles to measure metabolic rate (e.g. Wallace et al. 2005). Deuterium is not discussed further here because all other studies analysed naturally occurring isotopic ratios within tissues. A single radioactive isotope species $\left({ }^{14} \mathrm{C}\right)$ was also analysed from hawksbills Eretmochelys imbricata (Van Houtan et al. 2016).

$\mathrm{C}$ and $\mathrm{N}$ isotopes most likely dominate the literature because of well-understood relationships with diet and trophic position across many taxa, wellestablished processing methods, and lower analysis costs compared with other isotopes. In marine turtles, combined analyses of $\mathrm{C}$ and $\mathrm{N}$ isotopes have been used to identify foraging habitat type and/or specific geographical foraging areas, due to variation caused by different geochemical properties and/or resource use between locations (e.g. Hatase et al. 2010, Vander Zanden et al. 2015), or between life history phases (Arthur et al. 2008).

\section{Methodological studies}

Methodological studies investigating variation in isotopic signals in specific animals, tissues, and techniques for preparing and/or preserving samples are fundamentally important for allowing inferences into the ecology of the target species (Rubenstein \& Hobson 2004). Without understanding these drivers of variation, it is not possible to infer broader ecological patterns. Thus, this type of study is fundamentally important to the use of SIA techniques. However, identifying the RMUs used in these methodological studies is less important to their outcomes and broader implementation than it is for the geographic studies we consider later. Therefore, we consider methodological studies at the broader species level, rather than the specific RMU in which the study was conducted.

\section{Diet-tissue relationship}

Studies investigating the relationship between a turtle's diet and the isotopic values in their tissues have accounted for a large proportion of the literature to date. We found 39 papers investigating this relationship (Table 2) through sampling the isotopic ratios of potential food sources and comparing

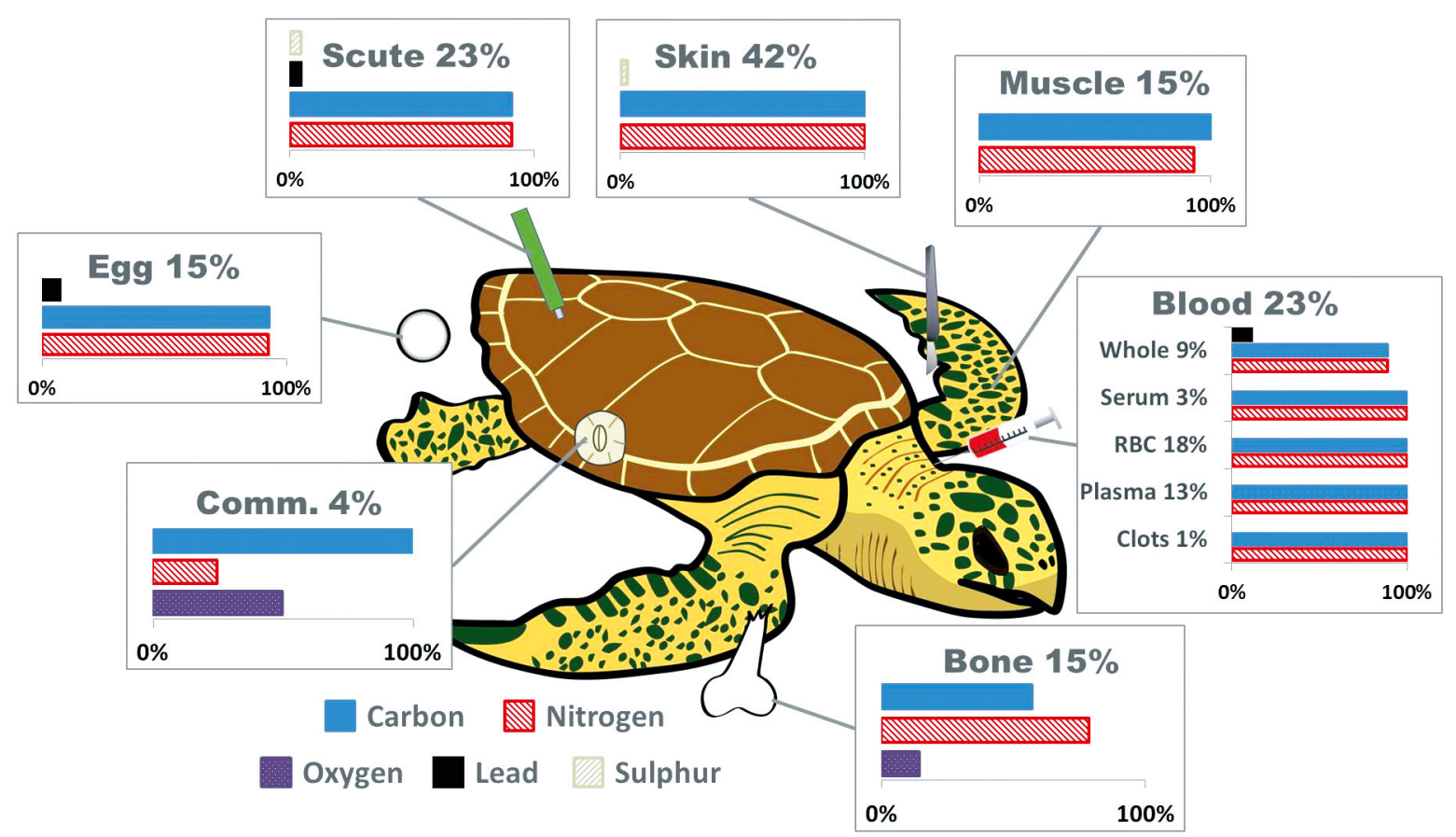

Fig. 2. Percentage of papers using each tissue type in sea turtle isotope studies, and the percentage of studies within each tissue type that analysed each isotopic element (bars). Blood percentage is total using any blood tissue type. RBC: red blood cells; Comm.: commensals. Further tissue types not represented here are: liver (3 studies), tendon (1), flipper scale (1) 
Table 2. Number of methodological studies per species. Diet-tissue relationship: studies that compare stable isotope values in sea turtle tissues to those of potential diet sources. Tissue-tissue relationship: studies that compare stable isotope values between different tissue types from the same turtle, including those that compare between mother and egg or hatchling. Isotopic/metabolic turnover: studies that evaluate the residence time of isotopes within turtle tissues. Sample preservation and preparation: studies which test the effect of different preservative and/or preparation methods on isotopic signals. Fossil isotopes: studies that have investigated isotopes from turtle and epibiont remains $>500 \mathrm{yr}$ old. A single study that falls into multiple categories will be represented multiple times in both rows and columns

\begin{tabular}{|lcccccc|}
\hline Species & $\begin{array}{c}\text { Diet- } \\
\text { tissue }\end{array}$ & $\begin{array}{c}\text { Tissue- } \\
\text { tissue }\end{array}$ & $\begin{array}{c}\text { Isotopic/ } \\
\text { metabolic }\end{array}$ & $\begin{array}{c}\text { Preserve/ } \\
\text { prep }\end{array}$ & $\begin{array}{c}\text { Fossil } \\
\text { isotopes }\end{array}$ & Total \\
\hline Flatback & - & - & - & - & - & 0 \\
Green & 22 & 10 & 1 & 5 & 1 & 39 \\
Hawksbill & 3 & 1 & - & - & - & 4 \\
Kemp's ridley & 1 & - & - & - & - & 1 \\
Leatherback & 5 & 6 & 1 & - & 1 & 13 \\
Loggerhead & 15 & 16 & 1 & 6 & 1 & 39 \\
Olive ridley & 3 & 4 & 1 & 1 & - & 9 \\
\hline
\end{tabular}

Captive feeding studies have also provided a valuable understanding of the relationship between diet and tissue isotopes. Seminoff et al. (2006) fed captive green turtles a controlled diet for $619 \mathrm{~d}$ and measured the effect on various tissues. Isotopic discrimination values were demonstrably different between tissue types (skin, whole blood, red blood cells, plasma). For example, $\delta^{13} \mathrm{C}$ diet-tissue discrimination ranged from -0.92 to $0.17 \%$ and $\delta^{15} \mathrm{~N}$ from 0.57 to $2.80 \%$ across these tissues. Comparing these values to those from the same tissues in leatherbacks (range: -0.58 to $2.25 \%$ or $\delta^{13} \mathrm{C}$ and 1.49 to $2.85 \%$ o for $\delta^{15} \mathrm{~N}$ ) further demonstrates differences in discrimination values between species (Seminoff et al. 2009). This indicates a need to develop

these to the signals in turtle tissues (e.g. McClellan et al. 2010, Shimada et al. 2014), or by feeding captive turtles a diet of known isotopic composition and measuring the effect this had on tissue ratios (e.g. Seminoff et al. 2006, Reich et al. 2008). The use of mixing models in this type of study allows researchers to elucidate the proportional contribution of different prey items to an animal's diet based on isotope ratios from the consumer's tissues (see Phillips et al. 2014 for review of isotope mixing models). In the sea turtle literature, prominent mixing model tools are IsoSource (e.g. Cardona et al. 2009), SIAR (e.g. Lemons et al. 2011) and MixSIAR (e.g. Sampson et al. 2017).

These studies have provided valuable insights into the feeding ecology of marine turtles. For example, green turtles were once believed to be almost entirely herbivorous after recruiting to neritic feeding areas, but studies both within (e.g. Cardona et al. 2009) and beyond (e.g. Arthur et al. 2007) the isotopic literature have revealed that animal prey can contribute significantly to neritic green turtle diets. Stable isotopes have also been used to demonstrate regular switches between diet sources (e.g. macroalgae, mangrove, and seagrass) in green turtles (e.g. Prior et al. 2015), complimenting findings from other techniques such as stomach content analyses (e.g. Limpus \& Limpus 2000). Lastly, ontogenetic shifts in resource and habitat use have been demonstrated through analysis of sequential scute layers (e.g. Reich et al. 2007), sequential blood sampling (Goodman Hall et al. 2015) and across green turtle age classes (Arthur et al. 2008). a base-level understanding of isotopic discrimination for each species prior to using stable isotopes in marine turtle geographic or food web studies. Diet-tissue discrimination factors can also differ among life stages (Reich et al. 2008, Vander Zanden et al. 2012b).

CSIA is also a powerful tool for food web studies that allows separation of the effects caused by trophic level and baseline differences in primary producers, something that is difficult to achieve using bulk tissue isotopes alone (McClelland \& Montoya 2002). This is possible by targeting specific amino acids which, in some cases, retain the isotopic ratios from the primary producer at the base of the food web (e.g. phenylalanine), while others increase with trophic level (e.g. glutamic acid) (McClelland \& Montoya 2002, Seminoff et al. 2012). Comparing the two can allow identification of baseline values and trophic level without the need to sample a wide variety of potential food sources necessary for mixing models. We found 3 studies that used CSIA techniques on sea turtles (Seminoff et al. 2012, Vander Zanden et al. 2013, Arthur et al. 2014) that have each provided valuable insights into the feeding ecology and/or foraging location of sea turtles.

\section{Tissue-tissue relationship and isotopic turnover}

We defined the tissue-tissue relationship category as studies that evaluated isotopic ratios from more than one tissue, including those that investigated the isotopic signals in both mother and offspring. We found 24 studies that investigated this relationship 
across 5 species (Table 2). We further defined the isotopic turnover category as studies that investigated the residence time of isotopes within various turtle tissues (see Table 1 for combined $\mathrm{C}$ and $\mathrm{N}$ values). While both categories are different, we combined them in this section because they are generally investigated simultaneously (e.g. Reich et al. 2008).

The tissue selected for isotopic analyses is important because of variations in turnover rate/residence time and isotopic ratios among tissues (Seminoff et al. 2006, Reich et al. 2008). Isotope residence time within specific tissues affects the length of isotopic history that can be inferred, and tissue-tissue discrimination affects the ability to identify the underlying driver behind isotopic variability, and the ecological inferences that can be gleaned from analyses. For example, Reich et al. (2008) demonstrated that isotopic assimilation into tissues varies with age class and tissue type. In hatchling and juvenile loggerhead turtles, skin and red blood cells (RBCs) showed the longest isotopic residence time, and blood plasma the shortest (Table 1). Individual scute layers and whole blood were intermediate (Reich et al. 2008). No studies investigated residence times in sea turtle muscle or liver (Table 1).

Growth rate is expected to be a major driver of isotopic residence time in animal tissues, with faster growing life stages exhibiting the shortest residence times (Rubenstein \& Hobson 2004). However, Reich et al. (2008) surprisingly showed that hatchlings had longer residence times for some tissues than juvenile turtles (Table 1). Adult turtles presumably turn over stable isotopes at a slower rate than hatchling and juveniles based on relationships between growth rate, body size, and tissue turnover in other taxa (Rubenstein \& Hobson 2004). However, the residence time in adult sea turtle tissues has not been studied for any species (Table 1). Given that the relative residence times for hatchlings and juveniles somewhat conflict with findings for other taxa, this is an important gap in the literature.

\section{Sample preservation and/or preparation}

A range of techniques has been utilised throughout the turtle isotope literature, making comparisons between studies problematic. Within species, age classes, and tissue types, the choice of preservative and preparation techniques can alter isotopic signals, independent of any natural influences. It is therefore necessary to establish the effects of different preservatives and preparation methods on the isotopic signals of each species and tissue prior to inferring any ecological meaning from isotopic analyses. We identified 10 studies that investigated the effect of various preservation and preparation techniques on the stable isotopic signals of different sea turtle tissues (e.g. Barrow et al. 2008, Medeiros et al. 2015) (Table 2). Almost all focused on loggerhead and/or green turtle tissues (e.g. Kaufman et al. 2014, Bergamo et al. 2016) with only one study looking at olive ridley tissues (Carpena-Catoira et al. 2016). Similarly, all focused on the effect of these techniques only on $\mathrm{C}$ and $\mathrm{N}$ isotopes. The most thoroughly investigated turtle tissue in these studies is skin (5 studies) followed by bone (3), muscle (2), and one each for egg, flipper scale, and blood (whole blood, RBC, and plasma, separately).

Barrow et al. (2008) tested the effect of 5 common preservatives on the isotopic signals in loggerhead and green turtle epidermis. Preservation in ethanol or saturated $\mathrm{NaCl}$ solution did not yield significantly different $\mathrm{C}$ or $\mathrm{N}$ ratios (after $60 \mathrm{~d}$ ) from simply drying in a $60^{\circ} \mathrm{C}$ oven. In many field situations, immediately drying in an oven is likely to be impractical, leaving ethanol or saturated $\mathrm{NaCl}$ solution as the most appropriate techniques for preserving tissue from sea turtles. Surprisingly, a significant difference was noted at the $60 \mathrm{~d}$ mark for samples kept frozen at $-10^{\circ} \mathrm{C}$. Preservation in a dimethyl sulfoxide (DMSO)-ethylenediaminetetraacetic acid (EDTA) buffer (a common preservative in genetics analyses) also resulted in significantly different isotopic results, suggesting that this preservative should not be used on turtle skin in isotopic studies (Barrow et al. 2008). However, the effect of a particular preservative on one tissue cannot necessarily be extrapolated across other tissue types and species. For example, ethanol was demonstrated to significantly alter the $\mathrm{C}$ isotopic signal in loggerhead egg yolk (Kaufman et al. 2014).

Various studies have also investigated the effect of lipid extraction (e.g. Carpentier et al. 2015), with some specific focus on isotopic signals in eggs (Kaufman et al. 2014), epidermis (Vander Zanden et al. 2014), and bone collagen (Medeiros et al. 2015). Kaufman et al. (2014) found that lipid extraction significantly altered $C$ isotopes in loggerhead egg yolk, while Vander Zanden et al. (2014) found no effect from this practice in loggerhead skin. This is not surprising given the low concentration of lipids in skin tissue (Vander Zanden et al. 2014) and the wellestablished linear relationship between lipid content and $\delta^{13} \mathrm{C}$ across many taxa (Post et al. 2007). Lipid extraction from turtle bone collagen elevated $\mathrm{C}$ ratios, but had no effect on N (Medeiros et al. 2015). How- 
ever, Turner Tomaszewicz et al. (2015) found no effect of lipid extraction on bone samples. These contrasting findings within and between tissue types again highlights the need for species- and tissuespecific validation of preparation methods.

Other studies have investigated various aspects of sample preparation for isotopic analyses. Decomposition (skin and muscle samples collected periodically from carcasses decomposing out-of-water at ambient temperature for up to $62 \mathrm{~d}$ ) was shown to have no effect on $\mathrm{C}$ and $\mathrm{N}$ isotope ratios (Payo-Payo et al. 2013). However, Frankel et al. (2012) reported a significant effect of decomposition in loggerhead hatchlings. Lemons et al. (2012) suggested that sodiumheparin is the best choice of blood anticoagulant as it has no observable effect on the $\mathrm{C}$ or $\mathrm{N}$ ratios in the most commonly studied green turtle blood tissues (plasma and RBC). However, sodium-heparin did cause some change to $\mathrm{N}$ ratios in whole blood. Other anticoagulants (such as acid citrate dextrose [ACD] and EDTA) altered either $\mathrm{C}$ or $\mathrm{N}$ isotope ratios in 2 of the 3 blood tissues tested (Lemons et al. 2012). Lastly, 2 studies combined to present recommended preparation (Turner Tomaszewicz et al. 2015) and extraction (Turner Tomaszewicz et al. 2016) methods for isotopic analysis of turtle cortical bone. These studies recommend that chemical treatment (e.g. acidification) is not necessary prior to SIA for green or loggerhead turtle bone layers.

\section{Future methodological research priorities}

Methodological studies are necessary to enable other study types (e.g. geographic or food web studies) and the broader ecological understandings they provide. Therefore, methodological studies should take priority over geographic studies for species in which they are limited or absent. We suggest that diet-tissue studies focused on flatback and Kemp's ridley turtles should be the highest priority in future isotope studies, given the complete lack of assessment of isotopes in these species (Table 2). Furthermore, developing a better understanding of the isotopic residence time in adult sea turtles would be of great benefit to future sea turtle isotope studies.

\section{Management relevance of SIA studies}

Many SIA studies have important management implications beyond pure methodological validation. For example, diet-tissue studies allow for analysis of food webs and identification of baseline resource requirements (e.g. McClellan et al. 2010, Burkholder et al. 2011), or timing of ontogenetic habitat shifts (e.g. Arthur et al. 2008, Goodman Hall et al. 2015). This allows managers to make decisions that preserve important habitat types at different life stages to support the food webs in which sea turtles feed. Similarly, analyses that investigate the degree of overlap between turtle diets and commercial fisheries/discards (e.g. Wallace et al. 2009) provide valuable insights that can inform fisheries managers in an effort to further support sea turtle conservation. Lastly, inferences from SIA about geographic locations (including how these change at the population level within and between nesting seasons) appear to provide a cost effective and high throughput alternative to satellite telemetry and tag recovery when environmental conditions allow for distinction between areas. For this reason, we consider SIA to be an important tool for management of threatened populations that should be used alongside tagging, satellite telemetry, and genetic studies to optimise conservation outcomes.

\section{Geographic studies}

In this section we separated the studies that derived geographic information from stable isotopes into individual RMUs, a spatial resolution that is relevant to managers (Table S3). The stable isotopes of turtle tissues or their commensal barnacles have been used to assign specific foraging areas to turtles in 20 studies (specific location), with a further 33 distinguishing between feeding habitats (habitat discrimination). Studies in the specific location category are those that aimed to assign geographic locations to turtles using SIA (e.g. Pajuelo et al. 2012, Vander Zanden et al. 2014). These almost all rely on a concurrent use of satellite telemetry to allow investigators to develop baseline signals that can then be used to develop isoscapes and assign untracked turtles to foraging areas. Habitat discrimination studies almost all separate turtles into those feeding in oceanic ( $>200 \mathrm{~m}$ depth) versus neritic $(<200 \mathrm{~m}$ depth) areas (e.g. Hatase et al. 2010). This is possible due to inherently different isotopic ratios among primary producers and the trophic levels at which turtles feed in these areas (Hatase et al. 2010). Habitat discrimination studies have identified the feeding habitats of adults, but also the timing of ontogenetic shifts in habitat use across age classes (e.g. Arthur et al. 2008), or across carapace layers, which are able to store a temporal record across a relatively long 
period, estimated to be up to 18 yr (Vander Zanden et al. 2016) (Table 1).

While most employ multiple isotopes (usually $\mathrm{C}$ and N), some studies find one isotope more useful than another. Some areas may have insufficient difference in isotopic ratio between geographic areas to allow for assignment of foraging areas based on isotopic values alone. For example, Vander Zanden et al. (2013) found wide variation in $\mathrm{C}$ and $\mathrm{N}$ isotopes in green turtles nesting at Costa Rica, but insufficient differentiation between areas to enable geographic assignment. Zbinden et al. (2011) also found insufficient geographic pattern in $\mathrm{C}$ isotopes in the Medi-

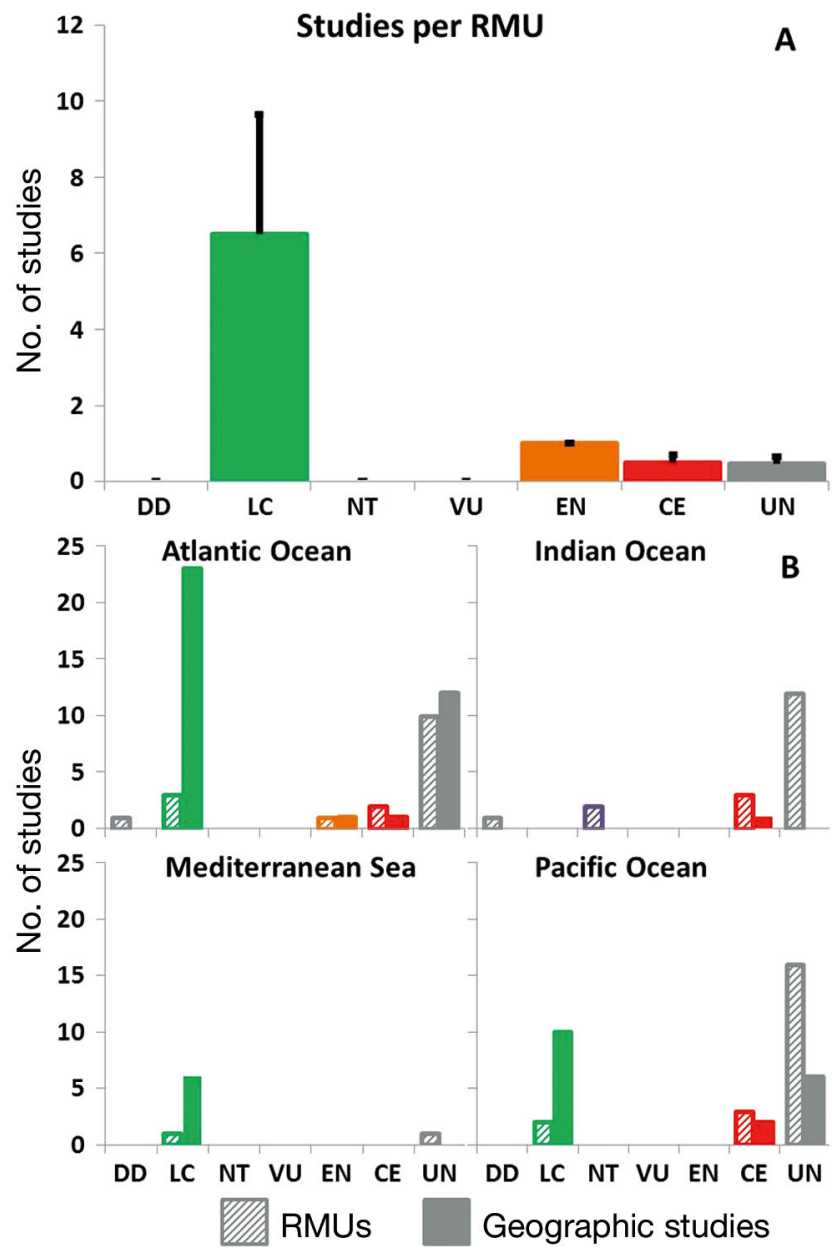

Fig. 3. Number of geographic isotope studies conducted per regional management unit (RMU) of each IUCN Red List threat level. (A) Mean $( \pm \mathrm{SE})$ number of studies globally per RMU of each threat level. (B) Number of sea turtle RMUs of each threat status versus the number of geographic isotope studies within each threat type in the 4 major oceans in which sea turtles occur. Note: only 18 of 58 RMUs have had IUCN assessments, but these 18 account for $69 \%$ of all geographic isotope studies. DD: Data Deficient; LC: Least Concern; NT: Near Threatened; VU: Vulnerable; EN: Endangered; CE: Critically Endangered; UN: Unassigned terranean Sea to be of use in assigning foraging areas to nesting turtles, but was able to do so using only $\mathrm{N}$ isotopes.

\section{Mismatch between geographic isotope studies and conservation priority}

Critically Endangered hawksbill turtles, and Data Deficient flatback turtles have not been the subject of any geographic isotope studies while the also Critically Endangered Kemp's ridley turtles have only recently received attention in their first isotope study (Reich et al. 2017; see Table S3 in the Supplement). Similarly, until recently, no geographic isotope studies had been conducted in the Indian Ocean, with the first (focused on leatherback turtles) published in early 2017 (Robinson et al. 2016). The Atlantic is the most studied ocean (particularly the northwest; Fig. 3B).

Approximately $69 \%$ of geographic isotope studies fall within RMUs with IUCN assessments. However, only 4 Critically Endangered RMUs have been studied: 3 leatherback RMUs (Seminoff et al. 2012, Robinson et al. 2016) and 1 Kemp's ridley RMU (Reich et al. 2017). Conversely, RMUs considered to be of Least Concern have been the subject of 39 geographic isotope studies $(\sim 74 \%$ of geographic studies; Fig. 3A, Table S3) at 6.5 papers per RMU. This is more than 6 times higher than the next most studied threat category, Endangered, at 1 paper per RMU (Fig. 3A) and approximately 13 times higher than all threatened categories combined (at 0.5 studies per RMU). There are a further 19 geographic isotope studies across the 39 unassigned RMUs (0.46 studies per RMU).

This mismatch between the effort applied to Threatened versus Least Concern RMUs could be a symptom of more robust science and management initiatives in the Least Concern populations, thus driving population recovery. Alternatively, it could have been driven by funding or ease-of-access. It could also be because there has been an abundance of satellite telemetry studies in these areas, allowing for isoscapes to be established more readily. Regardless of the cause, these findings suggest a need to guide future research towards the more threatened RMUs. As mentioned, recent publications indicate that this shift may have already begun, with the number of geographic studies on Threatened populations doubling (from 2 to 4) in 2017 (Eder et al. 2012, Seminoff et al. 2012, Robinson et al. 2016, Reich et al. 2017).

Even in the most studied species (loggerheads), 29 of the 30 geographic isotope studies were on 
Least Concern RMUs, and none at all in a Critically Endangered RMU (Table S3). We note that Arthur et al. (2014) did evaluate isotopes in south Pacific loggerhead tissues, which is listed as Critically Endangered, but with only 2 individuals from a similar location, this study did not attempt to discriminate between locations. Instead, Arthur et al. (2014) focused on diet, trophic level, and comparison to green and olive ridley turtles in different foraging areas. Given the sampling locations for each species, we consider this study to be a geographic isotope study for green turtles only, excluding it from the loggerhead Critically Endangered subpopulation analysis.

\section{Ecological significance and limitations of geographic studies}

While it is clearly important to understand resource use for management of foraging populations (e.g. the relative importance of seagrass/mangrove/algae), arguably the largest contribution that SIA can make to marine turtle conservation and management is through assigning foraging grounds for adults sampled in nesting or mating areas. This allows identification of critical habitats, and therefore for targeted management of specific threats within them. The correlation between the home foraging area of satellite tracked turtles and the isotopes in their tissues appears strong and has allowed numerous studies to assign foraging areas to untracked turtles once baseline foraging area signals have been established (e.g. Zbinden et al. 2011, Pajuelo et al. 2012, Vander Zanden et al. 2014). This is possible with, at times, high within-study accuracy (e.g. 88 to $91 \%$ in Vander Zanden et al. 2015).

Critical to the ability to assign foraging areas to turtles using SIA is that the variation in isotopic values of turtles within an RMU is greater between foraging areas than within a foraging area (i.e. from different diet choices). Whether diet or location is more influential is yet to be fully understood and may still be unachievable through SIA of turtle tissues due to the foraging behaviour of marine turtles. For example, individual loggerheads often have diverse diets within a foraging area (Limpus et al. 2001), which would likely lead to high within-area variation of isotope ratios. This has recently been demonstrated using isotopes, where areas with higher prey diversity for loggerhead turtles returned higher isotopic variation (Pajuelo et al. 2016). Thus, to assign foraging areas using soft-tissue isotopes in future studies, it will be important to first evaluate the relative contributions of diet versus location to isotope ratios in each foraging area. If variation in isotope ratios (driven by diet) is greater within an area than the differences between areas, then area assignment accuracy is likely to be low.

It is possible, with validation, that isotopes from individual layers of barnacle shells may provide an alternative to soft-tissue analysis for assigning foraging areas to nesting turtles. Killingley \& Lutcavage (1983) demonstrated that movement between estuarine and marine waters can be understood by evaluating changes in $\mathrm{C}$ and $\mathrm{O}$ isotopes across shell layers of the commensal barnacle Chelonibia testudinaria. In theory, this analysis provides a diet-independent view of water chemistry history (changes in temperature and salinity over time), and could potentially be used to recreate migratory pathways over larger distances. However, more recently Detjen et al. (2015) were unable to delineate large-scale oceanic movement using much smaller commensal barnacles Platylepas sp. from green turtles. This highlights that the applicability of this method across species and regions will rely on robust methodological validation at the barnacle species level, as well as appropriate regional conditions. Knowledge of the growth rate of barnacles is required to apply a temporal reference to isotopic ratios and a robust understanding of how isotopic species are incorporated into shell material is vital. Furthermore, target species must be present on large proportions of the turtle population, and there must be sufficient differences in isotope ratios between geographic areas. Some of this information exists for barnacle species beyond the turtle isotope literature (e.g. Killingley \& Newman 1982), though much is yet to be understood at a level that allows successful implementation of the method for this purpose.

\section{CONCLUSIONS}

Stable isotope analyses have provided insights into the feeding ecology and geographic distributions of sea turtles throughout the world. To date, SIA has aided in understanding the resource and foraging habitat use of some species in limited RMUs. SIA appears to be useful as a complimentary technique to other methods, and could be used to fill knowledge gaps that remain despite extensive research and monitoring of some populations using other techniques. Isotopes are rarely useful for identifying specific shape, size, and location of foraging areas on 
their own, and to date have been used to 'multiply' results using other tools (predominantly satellite telemetry). For an equivalent cost, SIA can allow analysis of foraging distributions across many more individuals than satellite telemetry, but with lower geographical resolution, and with faster turnaround times than mark-recapture (which may take decades to achieve a similar level of understanding). Softtissue SIA, with minimal extra effort, can also be used in combination with mark-recapture to understand resource use and food-web structure (e.g. Lemons et al. 2011). Thus, SIA can drastically expand the potential outcomes of other ecological investigations for minimal cost.

SIA will be more useful for some species than others due to differences in their ecology (e.g. leatherbacks are not known to remain in defined foraging areas, minimising usefulness). There also remain critical gaps in knowledge, especially for flatback turtles, isotopic residence times in adult tissues, the effect size of diet-choice versus home feeding area, and for geographic studies on threatened sub-populations. The pioneering work in sea turtle isotope ecology remains valuable and important, especially in terms of the methodological studies, but could now be better targeted with geographic studies aimed at species and RMUs under more serious threat of extinction.

\section{LITERATURE CITED}

Arthur KE, O'Neil JM, Limpus CJ, Abernathy K, Marshall G (2007) Using animal-borne imaging to assess green turtle (Chelonia mydas) foraging ecology in Moreton Bay, Australia. Mar Technol Soc J 41:9-13

Arthur KE, Boyle MC, Limpus CJ (2008) Ontogenetic changes in diet and habitat use in green sea turtle (Chelonia mydas) life history. Mar Ecol Prog Ser 362:303-311

Arthur KE, Kelez S, Larsen T, Choy CA, Popp BN (2014) Tracing the biosynthetic source of essential amino acids in marine turtles using $\delta^{13} \mathrm{C}$ fingerprints. Ecology 95: 1285-1293

Balazs GH (1980) Synopsis of biological data on the green turtle in the Hawaiian Islands. NOAA Technical Memorandum NMFS-SWFC-7. US Department of Commerce, Washington, DC

Barrow LM, Bjorndal KA, Reich KJ (2008) Effects of preservation method on stable carbon and nitrogen isotope values. Physiol Biochem Zool 81:688-693

* Bergamo TF, Botta S, Copertino M (2016) Lipid extraction in stable isotope analyses of juvenile sea turtle skin and muscle. Aquat Biol 25:1-6

Bowen BW (1995) Tracking marine turtles with genetic markers. Bioscience 45:528-534

Burkholder DA, Heithaus MR, Thomson JA, Fourqurean JW (2011) Diversity in trophic interactions of green sea turtles Chelonia mydas on a relatively pristine coastal foraging ground. Mar Ecol Prog Ser 439:277-293
Cardona L, Aguilar A, Pazos L (2009) Delayed ontogenic dietary shift and high levels of omnivory in green turtles (Chelonia mydas) from the NW coast of Africa. Mar Biol 156:1487-1495

Carpena-Catoira C, Ortega-Ortiz CD, Elorriaga-Verplancken FR (2016) Isotopic effects of different preservation methods on scales of olive ridley sea turtles (Lepidochelys olivacea) from the Mexican Central Pacific. Rapid Commun Mass Spectrom 30:2480-2486

* Carpentier AS, Booth DT, Arthur KE, Limpus CJ (2015) Stable isotope relationships between mothers, eggs and hatchlings in loggerhead sea turtles Caretta caretta. Mar Biol 162:783-797

Casale P, Tucker A (2015) Caretta caretta. The IUCN Red List of Threatened Species 2015. e.T83644804A83646294. http://dx.doi.org/10.2305/IUCN.UK.2015-4.RLTS.T83644 804A83646294.en (accessed 2 July 2016)

Ceriani SA, Roth JD, Sasso CR, McClellan CM and others (2014) Modeling and mapping isotopic patterns in the Northwest Atlantic derived from loggerhead sea turtles. Ecosphere 5:122

* Coulson AB, Kohn MJ, Shirley MH, Joyce WG, Barrick RE (2008) Phosphate-oxygen isotopes from marine turtle bones: ecologic and paleoclimatic applications. Palaeogeogr Palaeoclimatol Palaeoecol 264:78-84

DeNiro MJ, Epstein S (1978) Influence of diet on the distribution of carbon isotopes in animals. Geochim Cosmochim Acta 42:495-506

DeNiro MJ, Epstein S (1981) Influence of diet on the distribution of nitrogen isotopes in animals. Geochim Cosmochim Acta 45:341-351

*Detjen M, Sterling E, Gomez A (2015) Stable isotopes in barnacles as a tool to understand green sea turtle (Chelonia mydas) regional movement patterns. Biogeosciences 12: 7081-7086

*Eder E, Ceballos A, Martins S, Pérez-García H, Marín I, Marco A, Cardona L (2012) Foraging dichotomy in loggerhead sea turtles Caretta caretta off northwestern Africa. Mar Ecol Prog Ser 470:113-122

FitzSimmons NN, Limpus CJ (2014) Marine turtle genetic stocks of the Indo-Pacific: identifying boundaries and knowledge gaps. Indian Ocean Turtle Newsletter 20: 2-18

Frankel NS, Vander Zanden HB, Reich KJ, Williams KL, Bjorndal KA (2012) Mother-offspring stable isotope discrimination in loggerhead sea turtles Caretta caretta. Endang Species Res 17:133-138

Fry B (2006) Stable isotope ecology. Springer Science + Business Media, New York, NY

*Godley B, Lima EHSM, Åkesson S, Broderick AC and others (2003) Movement patterns of green turtles in Brazilian coastal waters described by satellite tracking and flipper tagging. Mar Ecol Prog Ser 253:279-288

Goodman Hall A, Avens L, Braun McNeill J, Wallace B, Goshe LR (2015) Inferring long-term foraging trends of individual juvenile loggerhead sea turtles using stable isotopes. Mar Ecol Prog Ser 537:265-276

* Hatase H, Omuta K, Tsukamoto K (2010) Oceanic residents, neritic migrants: a possible mechanism underlying foraging dichotomy in adult female loggerhead turtles (Caretta caretta). Mar Biol 157:1337-1342

*Howell LN, Reich KJ, Shaver DJ, Landry AM, Gorga CC (2016) Ontogenetic shifts in diet and habitat of juvenile green sea turtles in the northwestern Gulf of Mexico. Mar Ecol Prog Ser 559:217-229 
IUCN (2016) The IUCN Red List of Threatened Species. www.iucnredlist.org (accessed 2 July 2016)

Jones TT, Seminoff JA (2013) Feeding biology: advances from field-based observations, physiological studies, and molecular techniques. In: Wyneken J, Lohmann KJ, Musick JA (eds) Biology of sea turtles, Vol 3. CRC Press, Boca Raton, FL, p 211-248

Kaufman TJ, Pajuelo M, Bjorndal KA, Bolten AB, Pfaller JB, Williams KL, Vander Zanden HB (2014) Mother-egg stable isotope conversions and effects of lipid extraction and ethanol preservation on loggerhead eggs. Conserv Physiol 2:cou049

Killingley JS, Lutcavage M (1983) Loggerhead turtle movements reconstructed from ${ }^{18} \mathrm{O}$ and ${ }^{13} \mathrm{C}$ profiles from commensal barnacle shells. Estuar Coast Shelf Sci 16: 345-349

Killingley J, Newman W (1982) ${ }^{18} \mathrm{O}$ fractionation in barnacle calcite: a barnacle paleotemperature equation. J Mar Res 40:893-902

Lemons G, Lewison R, Komoroske L, Gaos A and others (2011) Trophic ecology of green sea turtles in a highly urbanized bay: insights from stable isotopes and mixing models. J Exp Mar Biol Ecol 405:25-32

Kemons GE, Eguchi T, Lyon BN, LeRoux R, Seminoff JA (2012) Effects of blood anticoagulants on stable isotope values of sea turtle blood tissue. Aquat Biol 14: 201-206

Limpus CJ, Limpus DJ (2000) Mangroves in the diet of Chelonia mydas in Queensland, Australia. Mar Turtle Newsl 89:13-15

Limpus CJ, de Villiers DL, de Villiers MA, Limpus DJ, Read MA (2001) The loggerhead turtle, Caretta caretta, in Queensland: feeding ecology in warm temperate waters. Mem Queensl Mus 46:631-645

McClellan CM, Braun-McNeill J, Avens L, Wallace BP, Read AJ (2010) Stable isotopes confirm a foraging dichotomy in juvenile loggerhead sea turtles. J Exp Mar Biol Ecol $387: 44-51$

McClelland JW, Montoya JP (2002) Trophic relationships and the nitrogen isotopic composition of amino acids in plankton. Ecology 83:2173-2180

McCutchan JH, Lewis WM, Kendall C, McGrath CC (2003) Variation in trophic shift for stable isotope ratios of carbon, nitrogen, and sulfur. Oikos 102:378-390

* Medeiros L, da Silveira Monteiro S, Petitet R, Bugoni L (2015) Effects of lipid extraction on the isotopic values of sea turtle bone collagen. Aquat Biol 23:191-199

Pajuelo M, Bjorndal KA, Reich KJ, Vander Zanden HB, Hawkes LA, Bolten AB (2012) Assignment of nesting loggerhead turtles to their foraging areas in the Northwest Atlantic using stable isotopes. Ecosphere 3:89

Pajuelo M, Bjorndal KA, Arendt MD, Foley AM, Schroeder BA, Witherington BE, Bolten AB (2016) Long-term resource use and foraging specialization in male loggerhead turtles. Mar Biol 163:235

Payo-Payo A, Ruiz B, Cardona L, Borrell A (2013) Effect of tissue decomposition on stable isotope signatures of striped dolphins Stenella coeruleoalba and loggerhead sea turtles Caretta caretta. Aquat Biol 18:141-147

* Phillips DL, Inger R, Bearhop S, Jackson AL and others (2014) Best practices for use of stable isotope mixing models in food-web studies. Can J Zool 92:823-835

Pilcher N, Chaloupka MY, Woods E (2012) Chelonia mydas (Hawaiian subpopulation). The IUCN Red List of Threatened Species 2012. e.T16285718A16285879. http://dx.
doi.org/10.2305/IUCN.UK.2012-1.RLTS.T16285718A162 85879.en (accessed 2 July 2016)

* Post DM, Layman CA, Arrington DA, Takimoto G, Quattrochi J, Montana CG (2007) Getting to the fat of the matter: models, methods and assumptions for dealing with lipids in stable isotope analyses. Oecologia 152:179-189

* Prior B, Booth DT, Limpus CJ (2015) Investigating diet and diet switching in green turtles (Chelonia mydas). Aust J Zool 63:365-375

* Reich KJ, Bjorndal KA, Bolten AB (2007) The 'lost years' of green turtles: using stable isotopes to study cryptic lifestages. Biol Lett 3:712-714

* Reich KJ, Bjorndal KA, Martínez Del Rio C (2008) Effects of growth and tissue type on the kinetics of ${ }^{13} \mathrm{C}$ and ${ }^{15} \mathrm{~N}$ incorporation in a rapidly growing ectotherm. Oecologia 155:651-663

* Reich KJ, López-Castro MC, Shaver DJ, Iseton C, Hart KM, Hooper MJ, Schmitt CJ $(2017) \delta^{13} \mathrm{C}$ and $\delta^{15} \mathrm{~N}$ in the endangered Kemp's ridley sea turtle Lepidochelys kempii after the Deepwater Horizon oil spill. Endang Species Res 33:281-289

* Robinson NJ, Morreale SJ, Nel R, Paladino FV (2016) Coastal leatherback turtles reveal conservation hotspot. Sci Rep 6:37851

Rubenstein DR, Hobson KA (2004) From birds to butterflies: animal movement patterns and stable isotopes. Trends Ecol Evol 19:256-263

* Sampson L, Giraldo A, Payán LF, Amorocho DF, Ramos MA, Seminoff JA (2017) Trophic ecology of green turtle Chelonia mydas juveniles in the Colombian Pacific. J Mar Biol Assoc UK, doi:10.1017/S0025315417001400

* Seminoff JA, Shanker K (2008) Marine turtles and IUCN Red Listing: a review of the process, the pitfalls, and novel assessment approaches. J Exp Mar Biol Ecol 356: 52-68

Seminoff JA, Jones TT, Eguchi T, Jones DR, Dutton PH (2006) Stable isotope discrimination $\left(\delta^{13} \mathrm{C}\right.$ and $\left.\delta^{15} \mathrm{~N}\right)$ between soft tissues of the green sea turtle Chelonia mydas and its diet. Mar Ecol Prog Ser 308:271-278

* Seminoff JA, Jones TT, Eguchi T, Hastings M, Jones DR (2009) Stable carbon and nitrogen isotope discrimination in soft tissues of the leatherback turtle (Dermochelys coriacea): insights for trophic studies of marine turtles. J Exp Mar Biol Ecol 381:33-41

* Seminoff JA, Benson SR, Arthur KE, Eguchi T, Dutton PH, Tapilatu RF, Popp BN (2012) Stable isotope tracking of endangered sea turtles: validation with satellite telemetry and $\delta^{15} \mathrm{~N}$ analysis of amino acids. PLOS ONE 7 : e37403

* Shimada T, Aoki S, Kameda K, Hazel J, Reich K, Kamezaki N (2014) Site fidelity, ontogenetic shift and diet composition of green turtles Chelonia mydas in Japan inferred from stable isotope analysis. Endang Species Res 25: 151-164

Tagliabue A, Bopp L (2008) Towards understanding global variability in ocean carbon 13. Global Biogeochem Cycles 22:GB1025

* Turner Tomaszewicz CN, Seminoff JA, Ramirez MD, Kurle CM (2015) Effects of demineralization on the stable isotope analysis of bone samples. Rapid Commun Mass Spectrom 29:1879-1888

* Turner Tomaszewicz CN, Seminoff JA, Avens L, Kurle CM (2016) Methods for sampling sequential annual bone growth layers for stable isotope analysis. Methods Ecol Evol 7:556-564 
Van Houtan KS, Andrews AH, Jones TT, Murakawa SKK, Hagemann ME (2016) Time in tortoiseshell: a bomb radiocarbon-validated chronology in sea turtle scutes. Proc R Soc B 283:20152220

Vander Zanden HB, Bjorndal KA, Inglett PW, Bolten AB (2012a) Marine-derived nutrients from green turtle nests subsidize terrestrial beach ecosystems. Biotropica 44: 294-301

Vander Zanden HB, Bjorndal KA, Mustin W, Ponciano JM, Bolten AB (2012b) Inherent variation in stable isotope values and discrimination factors in two life stages of green turtles. Physiol Biochem Zool 85:431-441

Vander Zanden HB, Arthur KE, Bolten AB, Popp BN and others (2013) Trophic ecology of a green turtle breeding population. Mar Ecol Prog Ser 476:237

Vander Zanden HB, Pfaller JB, Reich KJ, Pajuelo M and others (2014) Foraging areas differentially affect reproductive output and interpretation of trends in abundance of loggerhead turtles. Mar Biol 161:585-598

Vander Zanden HB, Tucker AD, Hart KM, Lamont MM and others (2015) Determining origin in a migratory marine vertebrate: a novel method to integrate stable isotopes and satellite tracking. Ecol Appl 25:320-335

Vander Zanden HB, Bolten AB, Tucker AD, Hart KM and others (2016) Biomarkers reveal sea turtles remained in oiled areas following the Deepwater Horizon oil spill.

Editorial responsibility: Graeme Hays,

Burwood, Victoria, Australia
Ecol Appl 26:2145-2155

*Wallace BP, Williams CL, Paladino FV, Morreale SJ, Lindstrom RT, Spotila JR (2005) Bioenergetics and diving activity of internesting leatherback turtles Dermochelys coriacea at Parque Nacional Marino Las Baulas, Costa Rica. J Exp Biol 208:3873-3884

*Wallace BP, Avens L, Braun-McNeill J, McClellan CM (2009) The diet composition of immature loggerheads: insights on trophic niche, growth rates, and fisheries interactions. J Exp Mar Biol Ecol 373:50-57

*Wallace BP, DiMatteo AD, Hurley BJ, Finkbeiner EM and others (2010) Regional management units for marine turtles: a novel framework for prioritizing conservation and research across multiple scales. PLOS ONE 5:e15465

*Wallace BP, DiMatteo AD, Bolten AB, Chaloupka MY and others (2011) Global conservation priorities for marine turtles. PLOS ONE 6:e24510

Wallace B, Tiwari M, Girondot M (2013) Dermochelys coriacea. IUCN Red List of Threatened Species. IUCN, Gland. http://dx.doi.org/10.2305/IUCN.UK.2013-2.RLTS. T6494A43526147.en (accessed 2 July 2016)

K Zbinden JA, Bearhop S, Bradshaw P, Gill B, Margaritoulis D, Newton J, Godley BJ (2011) Migratory dichotomy and associated phenotypic variation in marine turtles revealed by satellite tracking and stable isotope analysis. Mar Ecol Prog Ser 421:291-302

Submitted: June 6, 2017; Accepted: September 28, 2017

Proofs received from author(s): November 7, 2017 